\title{
Coccolith size rules - what controls the size of coccoliths during coccolithogenesis?
}

\author{
Baptiste Suchéras-Marx ${ }^{1}$, Sophie Viseur ${ }^{1}$, Charlotte E. Walker ${ }^{2}$, Luc Beaufort ${ }^{1}$, Ian Probert $^{3}$, Clara
} Bolton $^{1}$

1 Aix Marseille Université, CNRS, IRD, INRAE, Coll France, CEREGE, Aix-en-Provence, France

2 Department of Biology, University of York, York YO10 5DD, UK

3 Station Biologique de Roscoff, 29680 Roscoff, France.

* Corresponding author: sucheras-marx@cerege.fr

\begin{abstract}
Coccoliths are calcite platelets produced inside coccolithophore cells and extruded to form a covering on the cell surface called a coccosphere. The size of coccoliths is an important parameter often used to identify species, and observations on extant species have shown an influence of abiotic parameters (e.g., $\mathrm{CO}_{2}$, light, nutrient concentration) on coccolith size. However, the sometimes large range of coccolith sizes occurring within a single coccosphere questions the mechanisms controlling coccolith size. A link was previously shown between cell/coccosphere size and coccolith size called the "coccolithophore size rule". In this study, we query the mechanisms controlling the size of a coccolith during coccolithogenesis. Two working hypotheses are formulated: (1) coccolith size is smaller than cell diameter, and (2) coccolithogenesis mainly occurs during a specific growth phase (G1 interphase). We propose two numerical models (each with two variants) to test the constraining effect of these hypotheses on coccolith size distribution within a population. Neither model can accurately reproduce the size distribution of an empirical coccolith population, indicating that additional factors likely influence coccolith size. According to both hypotheses, the comparison of coccolith size and cell size is only pertinent at the time of formation of a coccolith. In light of these results, we suggest that application of the coccolithophore size rules model should be limited to multipopulational studies, and we confirm the basis of the link between coccolith number and cell cycle. The coccolith size rule model proposed here requires verification with further observations of coccolithophore and coccolith growth data.
\end{abstract}

\section{Introduction}

Coccoliths are small $(1-15 \mu \mathrm{m})$ platelets produced by unicellular coccolithophore algae. Made of calcite, coccoliths are produced intracellularly and are then extruded to cover the cell in the form of a test, called a coccosphere. There are two types of coccoliths: holococcoliths formed by small rhombohedral calcite crystals and heterococcoliths formed by relatively large and complex, interlocked calcite crystals. In the following text, only heterococcoliths will be discussed and referred to as "coccoliths". The capacity for calcification by coccolithophores can be tracked down to the Late Triassic ( $210 \mathrm{Ma}$; Gardin et al., 2012). The emergence of large-scale, massive pelagic calcification by coccolithophores and the resulting calcium carbonate accumulation, known as the Kuenen event (Roth, 1989), tremendously modified the regulation of the carbonate system and the carbon cycle in the oceans (e.g., Zeebe and Westbroek, 2003). This regulation depends on two factors i) the quantity of coccoliths produced and exported to the lithospheric reservoir, and ii) the mass of each coccolith produced (e.g., Suchéras-Marx and Henderiks, 2014). The quantification of coccolith mass is challenging and is often based on coccolith size and derived thickness estimations (e.g., Beaufort and Heussner, 1999; Young and Ziveri, 2000). More recently, new birefringence-based methods (Beaufort et al., 2014; Bollmann et al., 2014; Fuertes et al., 2014; Gonzáles-Lemos et al., 2018; Beaufort et al., 2021) and 3D reconstructions (Beuvier et al., 2019) have been developed to estimate coccolith mass independent of coccolith geometry models. Whichever the methodology adopted, micropaleontologists routinely measure coccoliths and their size is considered an important taxonomic criterion. Fossil coccolith size variations have also been linked to environmental 
conditions such as $\mathrm{CO}_{2}$ concentration, sea surface temperature and other environmental conditions (e.g., Bornemann and Mutterlose, 2006; Suchéras-Marx et al., 2010; Bolton et al., 2016) or used to reconstruct biological parameters like cell volume/surface and growth rate that are used for paleoenvironmental reconstruction (e.g., Henderiks and Pagani, 2008; Zhang et al., 2020).

A study published in 2008 highlighted the isometric linear relationship between coccolith and coccosphere sizes at the genus level in Coccolithus, Cyclicargolithus, Dictyococcites and Reticulofenestra (Henderiks, 2008; previously partly published in Henderiks and Pagani, 2007). Based on the assumption that the internal coccosphere diameter is equivalent to the cell diameter, a relationship between coccolith size and cell size was also established. This set of biometric rules (termed "coccolithophore size rules") was critical to comprehension of the biometric constraints of coccolith formation and clearly advanced the state-of-the-art on the mechanistic understanding of coccolith biometry. These coccolithophore size rules have been extensively applied to estimate coccolithophore cell size in the Cenozoic fossil record, providing a key parameter for, for example, the reconstruction of atmospheric $p \mathrm{CO}_{2}$ based on carbon isotope fractionation by coccolithophores (e.g., Henderiks and Pagani, 2007; Plancq et al., 2012; Bolton et al., 2016; Zhang et al., 2020). However, the coccolith size range within individual coccospheres is not negligible and can be almost as large as the coccolith size range within a species or population (Beuvier et al., 2019), thus calling into question the applicability of the coccolithophore size rules model. More recently, Gibbs et al. (2013) proposed a new model (hereafter called the cell geometry model) based on measurements of the length of one coccolith per coccosphere, coccosphere diameter and cell diameter (the latter deduced as in Henderiks, 2008). Cell diameter was observed to correlate with the number of coccoliths in the coccosphere and not with coccolith length. The authors argued that this pattern shows a link between coccolith production and the growth cycle of the cell, with a low number of coccoliths in the coccosphere corresponding to cells that have just divided, whereas a high number of coccoliths corresponds to cells that are about to divide (Bown et al., 2014). In the present study, we assess the isometric rule from Henderiks (2008) at the individual and population level. Based on data from a culture experiment, from the literature, as well as numerical modeling; this study identifies the relationship between coccolith and cell size as a key mechanism at the individual level and discusses the applicability of the coccolithophore size rules and cell geometry models at the population level for paleoenvironmental reconstructions.

\section{Biometric and mechanistic constraints}

The model presented in this study is centered on two hypotheses that are based on published and new experimental observations of coccolithophores and coccolith growth. Firstly, coccolith size is, at least partly, controlled by cell size (working hypothesis 1). In order to confirm this working hypothesis, we studied the evolution of coccosphere mass at high temporal resolution in a clonal Gephyrocapsa huxleyi culture strain (RCC1216 from the Roscoff Culture Collection) for which the relationship between coccolith size and coccolith mass has previously been reported (Beuvier et al., 2019). A multi-well plate containing a low-density culture of calcifying cells grown in K/2 culture medium (Keller et al., 1987) was placed on the stage of an inverted microscope, installed in a climate-controlled room $\left(20^{\circ} \mathrm{C}\right)$ and illuminated with large-spectrum white LED lights with an intensity of ca. $100 \mu \mathrm{mol} \cdot \mathrm{m}^{-2} \cdot \mathrm{s}^{-1}$. An image of the field of view (observed under cross-polarized light) was grabbed using a high-resolution digital camera every minute for 9 hours. The mass of individual coccospheres was estimated from their birefringence quantified from the images (Beaufort et al., 2014). The results provide a high-resolution time series of the evolution of coccosphere mass, which exhibited a stepwise increase over the 9-hour duration of the experiment (Fig. 1A). Nine steps were observed, each with a marked shift in mass interpreted as the moment when newly formed coccoliths were extruded from the cell where they were formed. The amount of calcite added to the coccosphere during these steps was estimated by subtracting the calcite mass preceding and following each plateau (using the mean of the plateau and the standard 
error for statistics; Fig. 1A). The shifts in calcite mass represent the mass of the coccolith produced at each step. The succession of extruded coccoliths resulted in an increase in coccolith mass through time (Fig. 1B). The relationship between coccolith mass and length in RCC1216 (Beuvier et al., 2019) was used to convert mass to size $\left(r^{2}=0.68, \mathrm{RMSE}=0.15 \mu \mathrm{m}\right.$ (added to standard error of mass estimates for statistics)). The diameter of the coccosphere, measured every 100 minutes (inset in Fig. 1C), increased constantly. A strong correlation was recorded between coccolith length and coccosphere diameter $\left(\mathrm{r}=0.94 ; \mathrm{r}^{2}=0.88 ; \mathrm{p}<0.001\left(\mathrm{H}_{0}\right.\right.$ : uncorrelated $) ;$ Fig. $\left.1 \mathrm{C}\right)$. When coccosphere diameter increased by a factor of 1.3, coccolith length increased by a factor of 1.6. Despite the lack of replicates, these observations confirm that coccolith size is at least partly controlled by cell size (working hypothesis 1). Since coccoliths are produced inside the cell, it is logical to conclude that coccoliths cannot be larger than the cell (Fig. 2), but observations are limited and it is not possible for example to confirm whether coccoliths always grow to take up the maximum space available within the cell (i.e., the inner cell diameter). Observations by Taylor et al. (2007) do tend to confirm this latter point, which will be explored later in this study. It is worth mentioning that working hypothesis 1 is the cornerstone of the coccolithophore size rules model (Henderiks, 2008).
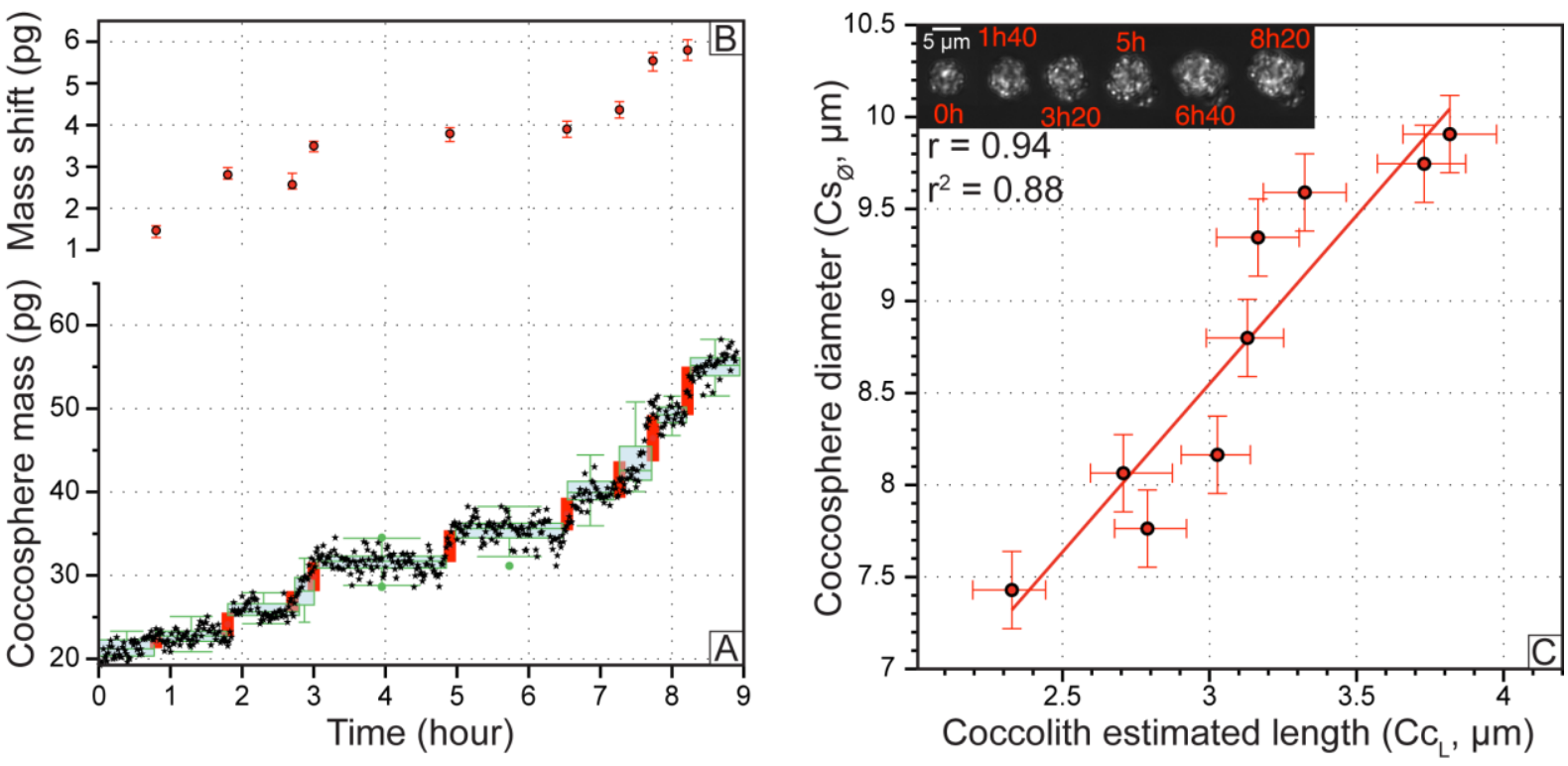

Fig. 1: Coccosphere mass with coccolith production through cell growth in a G. huxleyi culture. A. Cross-plot showing coccosphere mass through time during a $9 \mathrm{~h}$ experiment. Each vertical red bar shows a step in the increase of coccosphere mass corresponding to the production and addition of a coccolith to the coccosphere. B. The mass shift (red dots) corresponds to difference in mass before and after a step and represents the mass of the expelled coccolith. C. Cross-plot showing estimated coccolith length $(\mu \mathrm{m})$ based on coccolith mass measurement and coccosphere diameter $(\mu \mathrm{m}) ; \mathrm{n}=9 ; \mathrm{r}=0.94 ; \mathrm{r}^{2}=0.88$; $\mathrm{p}<0.001\left(\mathrm{H}_{0}\right.$ : uncorrelated); $\mathrm{Cs} \varnothing=1.829 \times \mathrm{Cc}_{\mathrm{L}}+3.0628$. The inset shows images of the coccosphere used to generate the data in the cross-plot.

Secondly, coccoliths are produced and extruded during the G1 interphase of the cell cycle (Müller et al., 2008; working hypothesis 2). The G1 interphase is the most important organic matter accumulation phase before mitosis that can result in an increase in density and/or size of the cell. According to previous observations (Müller et al., 2008; Walker et al., 2018), there is an increase in mean cell size during G1 interphase in coccolithophore cells. This working hypothesis is also confirmed by our experiment with the growth of coccosphere diameter during the phase of coccolith production (Fig. 1A-C). Combining 
hypotheses 1 and 2, coccoliths are successively produced during G1 interphase and coccolith size is partially controlled by cell diameter (Figs. 1-2).

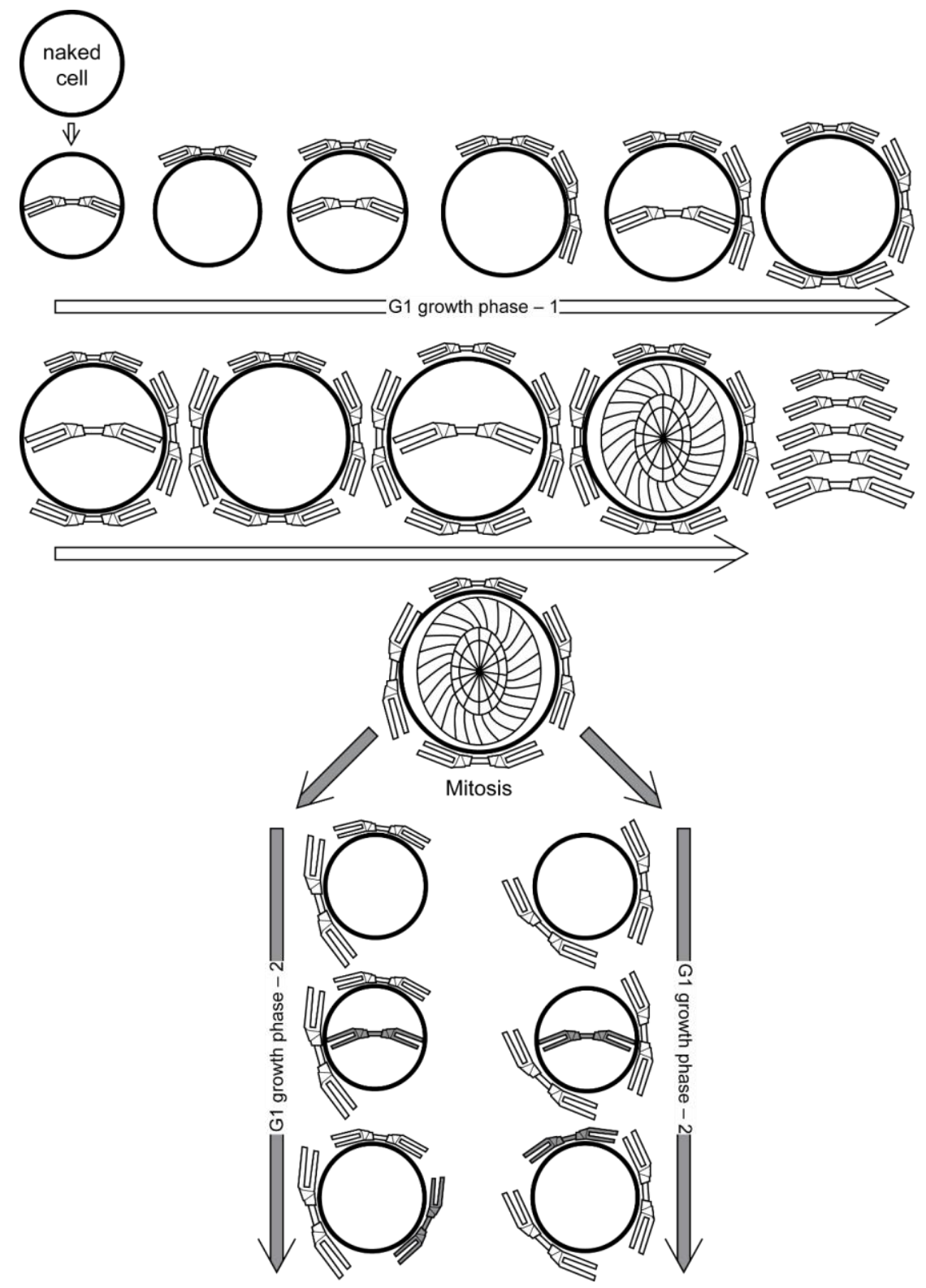

Fig. 2: Growth model starts from a naked cell with a G1 growth phase 1 producing coccoliths (white). The first G1 growth phase is ended with the expulsion of the fifth coccolith (in top view). When the growth phase is complete, two daughter cells are produced by mitosis. The coccoliths from the parent cell are shared between siblings following mitosis with possible coccolith loss. Then begins the process of coccolithogenesis to produce new coccoliths (grey) during the G1 growth phase 2 of daughter cells. In both growth phases, each coccolith is produced at the maximum size possible, i.e., the diameter of the cell (model I in the following). In the case of model II, a coccolith has a size between a fixed minimum size and the cell diameter when produced.

\section{Model parameters and mathematics}

We designed two numerical models in order to assess the reliability of our working hypotheses by simulating coccolith growth and exploring coccolith size rules. In both models, coccoliths are produced during a growth phase of the cell following working hypothesis 2 (Müller et al., 2008). The simulation algorithms rely on the following assumptions: i) cell growth is linear during G1 interphase; ii) coccolith 
production is constant during G1 interphase; iii) the simulations of coccolith size are independent events. These assumptions lead respectively to the following key points: i) cell diameter is modeled as a linear function; ii) coccolith production time is simulated using a Monte-Carlo sampling within a uniform density function between 0 (growth beginning) and 1 (growth end); iii) each time is simulated independently of previous simulated time values. In other words, for each simulation, a unique cell generates a unique coccolith generated randomly within the morphospace designed following different models (see hereafter). For each model and variant, 10000 simulations were conducted resulting in 10000 coccoliths, allowing a clear simulation of a population.

Beyond these main steps, the two models differ in the following aspects:

Model I: Every coccolith occupies the maximum space available within the cell, thus is equal in length to the cell diameter. We consider the cell diameter $\mathbb{C}_{\varnothing}$ to be directly linked to the coccosphere diameter Csø (i.e., the cell wall thickness is constant; Fig. 3A). This working hypothesis is coherent with observations in Taylor et al. (2007). However, this working hypothesis also constrains quite significantly the growth model. In this model, the coccolith diameter is directly estimated using a linear trend.

Model II: Each coccolith is produced at a size ranging from a minimum size virtually corresponding to the tube rim of the smallest coccolith to a maximum size equal to the cell diameter (Fig. 3B). This model gives a degree of liberty that is not possible in the deterministic model I. Coccolith diameter is simulated through a Monte-Carlo sampling in a uniform law between the minimum diameter and the cell diameter estimated linearly at the simulated time.

For both models, we also designed 3 simulation variants. Variant \#1 has the beginning (i.e., corresponding to $\mathscr{C}_{\varnothing} \mathrm{min}$ ) and end (i.e., corresponding to $\mathscr{C}_{\varnothing} \max$ ) cell diameter $\mathbb{C}_{\varnothing}$ fixed (labelled model I and model II) thus corresponding to a fixed growth slope (i.e., growth rate). Variant \#2 randomly generates $\mathscr{C}_{\varnothing}$ min and $\mathscr{C}_{\varnothing}$ max within a range with the same small degree of variability for the minimum and maximum cell diameter $\mathscr{C}_{\varnothing}$ (labelled model I' and model II'; Fig. 3C). This tends to change the growth slope within a range (i.e., simulate ranges in growth rates). Variant \#3 is similar to variant \#2 but with a stronger degree of variability for $\varnothing_{\varnothing}$ max than $\varnothing_{\varnothing}$ min (labelled model I" and model II"; Fig. 3C). The source code written in Python is available in Supplementary Information.

\section{Results}

\section{Coccolith growth during cell growth}

Based on both hypotheses 1 and 2, results about the relation between coccolith size and cell size can be deduced. The size of a coccolith size depends on the time during cell growth it is produced. After division of a cell which had no coccoliths, the cell will grow in diameter and periodically produce successively longer coccoliths (Fig. 2). Once maximum size is reached, cell growth and coccolith production will both stop. The cell will then divide into two, sharing its coccoliths between its daughter cells (Walker et al., 2018; Fig. 2). Hence, in a coccosphere:

- the size of each coccolith is directly proportional to the cell size when it was produced;

- coccolith size variability within a coccosphere depends on the cell size range;

- a coccolith can be inherited from a parent cell and thus its size is not related to the growth of the cell to which it is attached. 


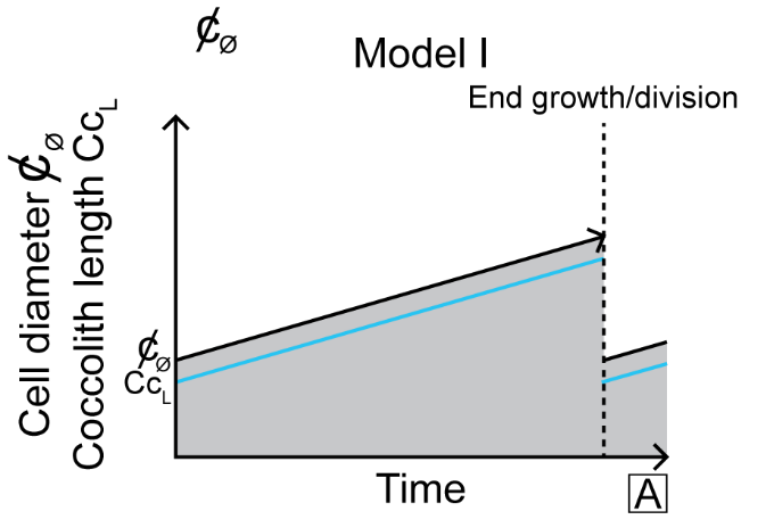

Models I'-II'

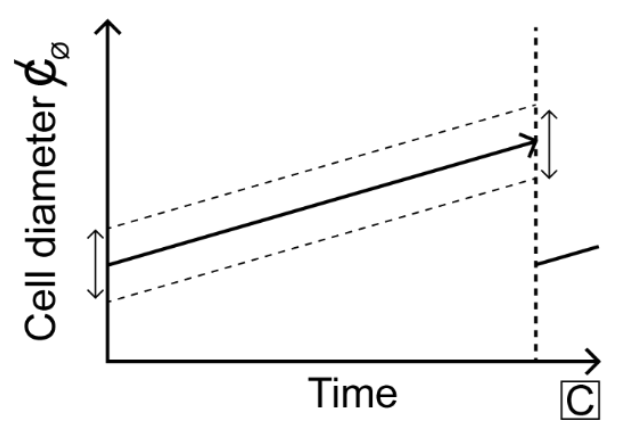

Model II

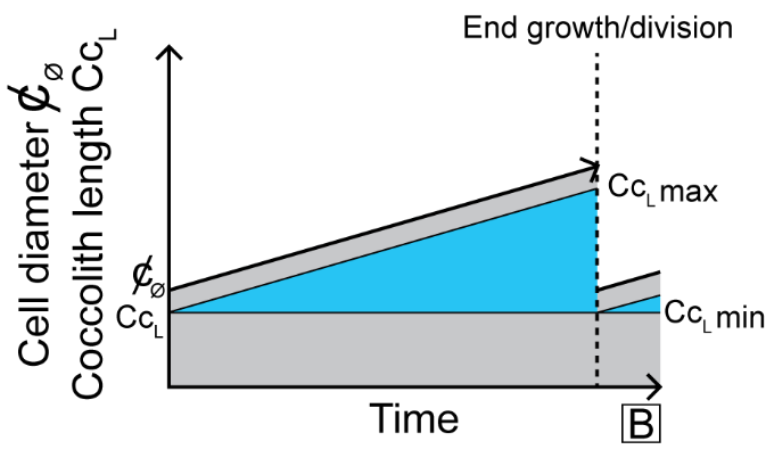

Models I"-II"

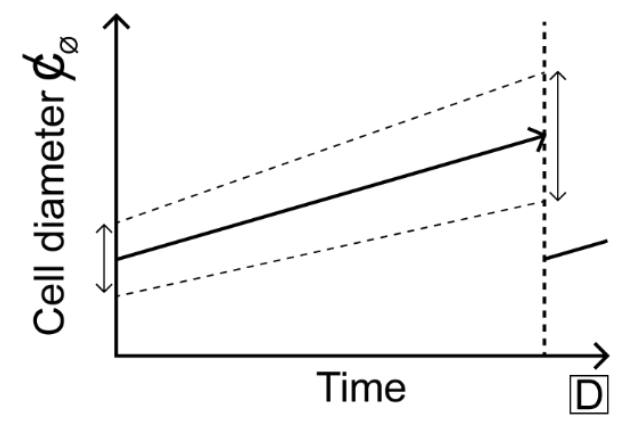

Fig. 3: A. Model I with each coccolith that grows to the maximum possible size (blue line) thus coccolith sizes follow cell size increases. B. Model II with each coccolith that grows to a size between a minimum $\left(\mathrm{Cc}_{\mathrm{L}} \min \right)$ and a maximum $\left(\mathrm{Cc}_{\mathrm{L}} \max \right)$, corresponding to the blue line in model $\mathrm{I}$. The blue area is the full morphospace of coccoliths. For each simulation, coccolith size is randomly sampled between min and max. C. Models I' and II' (i.e., variant \#2) with the beginning and end of cell growth having the same degree of liberty. D. Models I'" and II" (i.e., variant \#3) with the end having stronger degree of liberty than the beginning. In each model, only one coccolith is randomly produced in the timeline and for each model, 10000 simulations are conducted. Abbreviations: Cell $\mathscr{C}$, coccolith $\mathrm{Cc}$, cell outer diameter $\mathbb{C}_{\varnothing}$, coccolith length $\mathrm{Cc}_{\mathrm{L}}$.

\section{Simulated coccolith production}

The simulations from models I and II and variants (labelled I'-I', and II'-II') are represented in the form of Kernel Density Estimations (KDE, based on Gaussian kernel with range according to $\mathrm{h}=0.9$ $\min (\mathrm{s}, \mathrm{IQ} / 1.34) \mathrm{n}^{-1 / 5}$; Fig. 4) computed using PAST 3.25 (Hammer et al., 2001). Model I produces a rectangular shape because the borders have no degree of freedom and any size between beginning and end are equally likely to be sampled in the simulation (Fig. 4A). The shape is closer to a normal distribution in model I', both sides having a degree a freedom due to the possible changes in growth slope widening the morphospace, but it also leads to extreme values having less chance of being sampled (Fig. 4B). Model II gives a shape closer to a Pareto function with the left side being sharp because a minimum coccolith size limit is imposed, whereas the right side has a less steep slope (Fig. 4A) due to the morphospace that increase in size on the upper limit through time with the cell size increase (Fig. 3B). Model II' tends to smooth both sides by increasing the size of the morphospace, particularly visible on the very small coccolith size and decreasing the high occurrence of small coccoliths (Fig. 4B). Model I" and model II" introduce an asymmetry of the distribution (Fig. 4C). Model I' tends to increase the occurrence of large coccoliths, but the rectangular shape of the distribution is conserved. In model II", there is only a small increase in the occurrence of large coccoliths, but the mode tends to 
move to the right and the distribution is again wider. All results are very different from a Gaussian distribution, but in both models the derived version I'-II' tends to change the shape of the distributions closer to a Gaussian distribution.
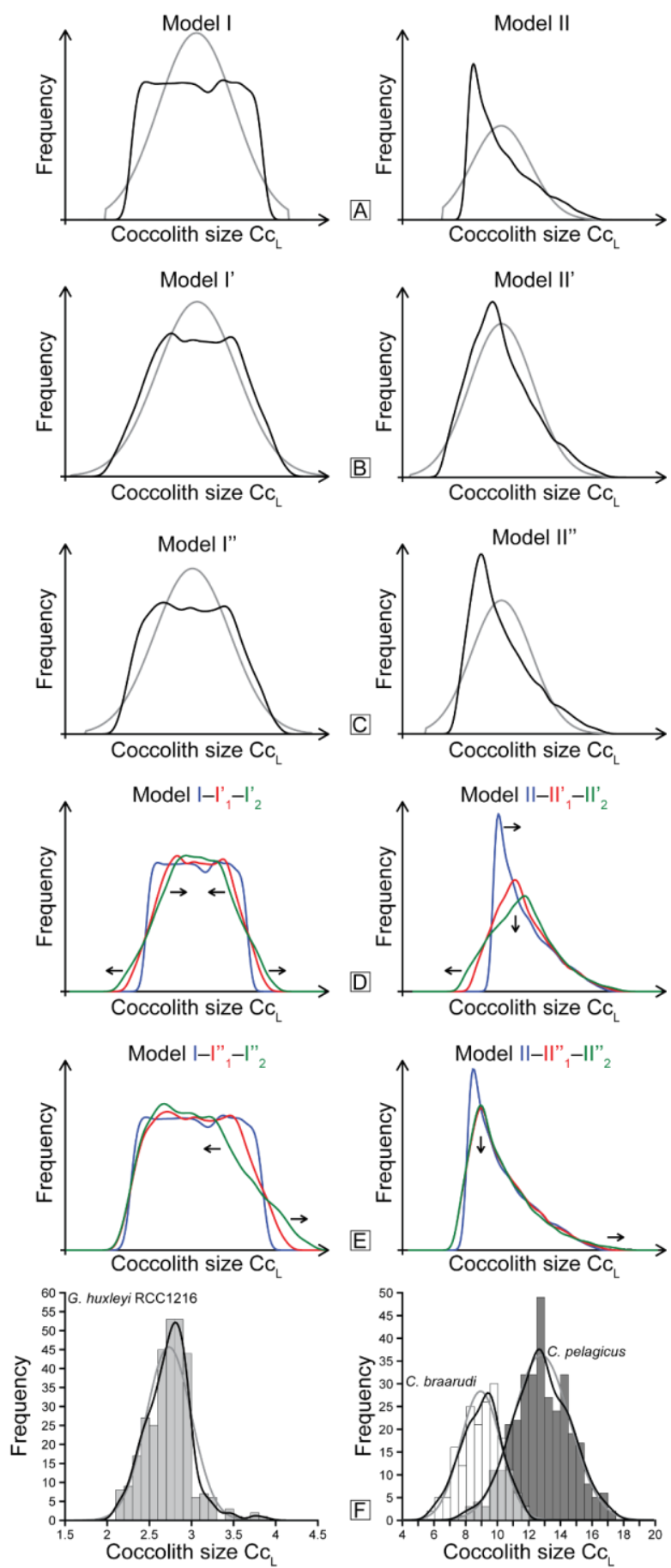

Figure 4: Results from model simulations presented in the form of Kernel density estimator of coccolith size $\mathrm{Cc}_{\mathrm{L}}$. A. Model I and model II with the black lines corresponding to the KDE and the grey lines to a fit of the result to a normal distribution. B. Same for model I' and model II'. C. Same for model I' and model II'. D. Comparison between model I and model I'. Model I' 1 gives less freedom on the borders than model I' ${ }_{2}$. Same for models II-II' ${ }_{1}$-II' ${ }_{2}$. E. Comparison between model I and model I'. Model I' gives less liberty on the right border than model I' ${ }_{2}$. Same for models II-II' ${ }_{1}-\mathrm{II}$ ' ${ }_{2}$. F. Coccolith size CcL distribution of cultured G. huxleyi (RCC1216; Beuvier et al., 2019; left) and Coccolithus braarudii and Coccolithus pelagicus (Daniels et al., 2014; right). 


\section{Discussion}

Modelling coccolith size distribution

Neither model I nor model II and their derivates can accurately reproduce the size distribution of an empirical coccolith population. Although the size distribution of a coccolith population is not systematically normally distributed (Supplementary Information), it does have a Gaussian-like distribution. The asymmetric models I' and II" both tend to increase the occurrence of very large coccolith size, but are very different from an empirical population. However, model I' and model II' tend to change the distribution towards a more Gaussian-like distribution. Model II' seems the closest to an empirical distribution, but still has a strong asymmetrical shape with a sharper slope on the left. The fact that none of the models designed here can reproduced the coccolith size distribution observed within an empirical population could indicate that working hypotheses 1 or 2 or both are false. However, both are based on observations of living coccolithophores and thus seem unlikely to be incorrect. Alternatively, if we assume that both hypotheses 1 and 2 are correct, a third factor controlling coccolith size is missing, potentially corresponding to variation in the rate of coccolith production. By design, growth rate was not considered in all models. This variable was excluded by producing only one coccolith randomly sampled during cell growth for each simulation. Because there are 10000 simulations, we correctly simulated a population. However, if there is a deterministic pattern in coccolith growth during G1 interphase, our models cannot capture this pattern which may shape coccolith size distribution. For example, it seems possible that coccolith growth during the beginning of G1 phase may be faster simply because coccoliths are smaller at this point and thus are produced more quickly. Such a pattern would also be species dependent, with small coccoliths (e.g., Chrysotila carterae) likely growing faster than large coccoliths (e.g., Scyphosphaera apsteinii). Furthermore, the increase in cell surface area during G1 interphase may increase the rate of $\mathrm{Ca}^{2+}$ and $\mathrm{HCO}_{3}{ }^{-}$transport into the cell for coccolith precipitation, but the increase in cell volume and change in cell surface/volume ratio may also influence coccolith growth rate. Further in situ observations and measurements are needed to constrain missing parameters influencing coccolith size during coccolithogenesis.

\section{Limitation of the coccolithophore size rules model}

Coccolithophore biometry is based on coccolith and coccosphere measurements. The coccosphere inner diameter is considered to be equal to cell size. Our analysis suggests that the positive linear correlation between cell size and coccolith size is only significant if the coccolith is measured directly after its extrusion onto the coccosphere, otherwise the cell may grow and the correlation between cell and coccolith sizes will decrease. Significantly, a coccolith in a coccosphere may be produced during a previous G1 interphase of a parent cell. Hence, at the scale of one complete coccosphere, there is no direct relationship between the estimated cell diameter and individual coccolith size. Therefore, the isometric coccolithophore size rules model is not applicable at the individual cell level. Moreover, this relationship between coccolith and cell size is also not observed in monospecific cultures at the population scale according to Sheward et al. (2017; data from Daniels et al., 2014) (Fig. 5) for Coccolithus pelagicus $\mathrm{r}=0.37 ; \mathrm{r}^{2}=0.14(\mathrm{n}=180)$ and Coccolithus braarudii $\mathrm{r}=0.15 ; \mathrm{r}^{2}=0.02(\mathrm{n}=329)$. However, plotting both of these datasets together results in an increase in the correlation coefficient and coefficient of determination with cultured Coccolithus $\mathrm{r}=0.53 ; \mathrm{r}^{2}=0.28$ ( $\mathrm{n}=509$ ) (Fig. 5). This observation is explained by the fact that a monospecific population has life cycle variability that is too high relative to its narrow cell size range. The isometric rule will be statistically more robust by increasing the cell size range by including other populations with different size ranges and/or other species belonging to the same genus (Fig. 5). Coccolithophore size rules in Henderiks (2008) were statistically robust because measurements were made i) at the genus level mixing species and intraspecies populations, ii) from two sites, one from the South Atlantic and the other from the North Atlantic thus sampling different geographic populations, and iii) over a long time interval spanning the middle 
Eocene to early Miocene thus sampling different populations that may have evolved in terms of cell size. Coccolithophore size rules thus represent evolutionary isometry (Shingleton, 2010), observed at a multi-population scale and not within a single population.

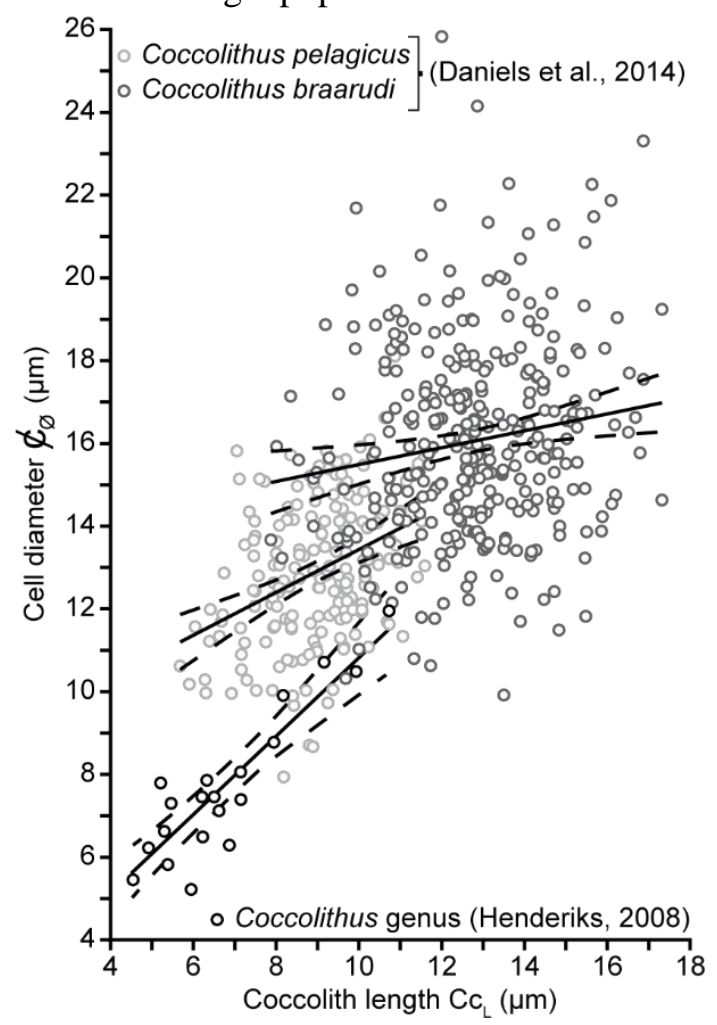

Figure 5: Coccolith length $\mathrm{C}_{\mathrm{L}}$ versus cell diameter $\bar{C}_{\varnothing}$ (based on coccosphere internal diameter measurements). Black circles correspond to fossil coccospheres from the Coccolithus genus (Henderiks, 2008), whereas light and dark grey circles correspond to cultured cells of Coccolithus pelagicus and Coccolithus braarudii, respectively (Daniels et al., 2014). Square root linear regressions were calculated using PAST3.25 (Hammer et al., 2001) with cultured Coccolithus pelagicus $\mathrm{n}=180 ; \mathrm{r}=0.37 ; \mathrm{r}^{2}=0.14$; $\mathrm{p}<0.001\left(\mathrm{H}_{0}\right.$ : uncorrelated $) ; \mathbb{C}_{\varnothing}=0.51778 \times \mathrm{Cc}_{\mathrm{L}}+8.2579$; culture Coccolithus braarudii $\mathrm{n}=329 ; \mathrm{r}=0.15$; $\mathrm{r}^{2}=0.02 ; \mathrm{p}=0.006\left(\mathrm{H}_{0}\right.$ : uncorrelated); $\not_{\varnothing}=0.20368 \times \mathrm{Cc}_{\mathrm{L}}+13.453$ and fossil Coccolithus $\mathrm{n}=21 ; \mathrm{r}=0.88$; $\mathrm{r}^{2}=0.78 ; \mathbb{C}_{\varnothing}=0.94 \times \mathrm{Cc}_{\mathrm{L}}+1.36$. Merging culture dataset results in Coccolithus $\mathrm{n}=509 ; \mathrm{r}=0.53 ; \mathrm{r}^{2}=0.28$; $\mathrm{p}<0.001$ ( $\mathrm{H}_{0}$ : uncorrelated); $\mathbb{C}_{\varnothing}=0.57966 \times \mathrm{Cc}_{\mathrm{L}}+8.3142$.

\section{Validation of the cell geometry model}

The cell geometry model proposes the deduction of coccolithophore division rate based on the correlation between the number of coccoliths within a coccosphere and coccosphere diameter (e.g., Gibbs et al., 2013; Daniels et al., 2014; Sheward et al., 2017). The theory behind this model is that cells that have just divided have a low number of coccoliths per coccosphere, and cells that are ready to divide have a high number of coccoliths per coccosphere. This model is consistent with coccoliths being produced during G1 interphase before mitosis, although this was not explicitly formulated by the authors (Gibbs et al., 2013; Bown et al., 2014). During cell growth, the coccolithophore will continuously add coccoliths. When the cell divides, coccoliths are shared between two daughter cells (Walker et al., 2018; Fig. 2). As previously mentioned, the absence of a relationship between coccolith and cell sizes for one individual cell can be explained by the fact that coccoliths are proportional in size to a particular point in the cell growth cycle, and coccoliths forming the coccosphere can record through time as many cell growth phases as the cell itself (Fig. 2). This is confirmed by the observation of small cells with very large coccoliths. In Daniels et al. (2014), 10\% of C. braarudii samples had coccoliths longer than the cell diameter. Those coccoliths were most likely produced by a parent cell rather than the cell currently 
hosting them. After division, the cell will again grow, increasing its surface area that will be covered by newly produced coccoliths. Hence, coccospheres with a very low number of coccoliths are likely to have recently divided or be at the beginning of G1 interphase, whereas coccospheres with a high number of coccoliths are likely at the end of G1 interphase and thus close to division, validating the cell geometry model proposed by Gibbs et al. (2013) and Bown et al. (2014).

\section{Measuring coccoliths for paleoenvironmental reconstructions}

Coccolith biometry is often used in micropaleontology for paleoenvironmental reconstructions because coccolith size is related to cell size in most placolith genera, which in turn is influenced by abiotic factors (e.g., Bolton et al., 2016). However, as discussed, the size of a coccolith is also linked to the cell growth cycle and by growth rate which is broadly negatively correlated with cell size (Aloisi, 2015). The size of the coccosphere/cell within a population is also influenced by ecological interactions such as predation (Monteiro et al., 2016). The size of a single coccolith is thus influenced by three types of factors with different time ranges (hours to days for cell growth, days to seasons for ecological interactions, days to millennia for abiotic factors) complicating the interpretation of such data. As an example, the size of a species holotype cannot be a strict and robust reference for a population or a species because coccoliths have variable sizes within a range linked to the cell growth cycle. Hence, the size of a holotype cannot be used for paleoenvironmental reconstruction as previously suggested by Erba et al. (2010) who used holotype sizes of several species to deduce dwarfism due to oceanic acidification during Aptian oceanic anoxic event 1a.

When applying biometry studies with paleoenvironmental goals (e.g., to reconstruct temperature (Bollmann, 1997), salinity (Bollmann et al., 2009) or $\left[\mathrm{CO}_{3}{ }^{2-}\right]$ (Beaufort et al., 2011)), a sufficient quantity of coccoliths and coccospheres within a population should be sampled to identify the cell growth cycle factor influencing size variation and/or a dataset that includes several species with different size ranges should be used. In this manner, the influence of ecological interactions or abiotic parameters should be able to be identified. As an example, Ferreira et al. (2017), who explored the information contained in size variations of the Lotharingius genus, minimized the uncertainty generated by the cell growth cycle by working on a whole genus and on a long-time interval and thus can clearly discuss environmental versus evolutionary (or ecological) forcing on coccolith size variations. Similarly, biometric studies at the scale of a family over short- (e.g., Badger et al., 2019) or long-time scales (e.g., Henderiks and Pagani, 2008) should sample enough of a population to minimize the uncertainty generated by the cell growth cycle. Inversely, biometric studies at the scale of a unique species over a long-time scale may also sample several populations to limit the uncertainty linked to the cell growth cycle variability (Gollain et al., 2019). The understanding of coccolith size in terms of cell growth, ecological interactions, evolutionary trends or environmental proxies is thus only possible with statistically robust sampling.

\section{Conclusion}

Coccolith size has been considered to be a key parameter to monitor past environmental changes such as ocean acidification (e.g., Erba et al., 2010; Beaufort et al., 2011). This was partly based on the coccolithophore size rules model linking the size of coccoliths to the size of the cell, and the fact that cell size is influenced by environmental conditions. Henderiks (2008) was clearly innovative and revolutionized biometric studies on coccoliths but the coccolithophore size rules have limitations that have often been ignored in subsequent studies. Such limitations are highlighted by observations of an important size range of coccoliths within individual coccospheres (e.g., Beuvier et al., 2019) and by the presence of large coccoliths on small coccospheres (e.g., Daniels et al., 2014). We validate the coccolith size rules based on the facts that coccoliths grow inside the cell during the GI interphase of the cell cycle and their growth is limited by cell diameter. However, alone these two hypotheses cannot fully 
reproduce the coccolith size distribution of a monospecific population, thus a third parameter is missing in our model. However, model I' and II' and the general rules stand, offering a satisfactory approximation of the mechanism constraining coccolith size during coccolithogenesis. Together, these biomechanical constrains result in the fact that within a coccosphere, coccolith size is linked to cell diameter when the coccolith was produced, and a coccolith hosted by a cell may have been produced by a parent cell. These observations thus exclude the application of coccolithophore size rules on samples restricted to a single population or even a single species. Conversely, our model confirms the cell geometry model, albeit linking growth cycle observations to multi-millennial environmental perturbation is outside the scope of this study. Lastly, understanding both coccolithophore size rules and coccolith size rules is necessary when undertaking a biometric study on coccoliths. The coccolith size rules model presented here, as well as the coccolithophore size rules, are limited to placolith heteroccoliths. For example, the model is likely not applicable to Braarudosphaera bigelowii which produces coccoliths outside of the cell (Hagino et al., 2016), holococcoliths which have a different crystallographic structure (Langer et al., 2021), highly elongated cells such as Placorhombus ziveriae or Calciosolenia brasiliensis (Young et al., 2003), or coccolithophores with a very high number of coccoliths and very low coccolith size variability (e.g., Florisphaera profunda, Coronosphaera maxima; Young et al., 2003). Further coccolith growth and cell life cycle observations of various species are critically needed to extend the taxonomic range of applicability of the coccolith size rules model.

\section{Acknowledgments}

BSM deeply thanks Thomas Beuvier for asking - during the writing of Beuvier et al. (2019) - why coccoliths from a single coccosphere have such different sizes? Rosie Sheward is warmly thanked for sharing her biometric data and knowledge on Coccolithus pelagicus and C. braarudii cultures. Jorge Ferreira kindly commented an early version of the manuscript. Julien Clavel is thanked for his critical comments on statistics. LB thanks the Fondation pour la Recherche sur la Biodiversité and the French Ministère de l'écologie who provided funding for the inverted optical microscopy within the COCCACE project. This manuscript is a contribution of team 'Climat' at CEREGE, OSU Pythéas, AMU.

\section{Author contributions}

The authors are listed from the most important contributor to the least. BSM designed the study, the model and wrote the manuscript. SV designed and carried out the simulations and wrote the dedicated part in the appendix. CW provided information on coccolithophore growth and commented on the models. LB and IP designed and conducted the coccolithophore growth experiment. All authors have contributed to the final version of the manuscript.

\section{References}

Aloisi, G., 2015. Covariation of metabolic rates and cell size in coccolithophores. Biogeosciences 12, 4665-4692.

Badger, M.P.S., Chalk, T.B., Foster, G.L., Bown, P.R., Gibbs, S.J., Sexton, P.F., Schmidt, D.N., Pälike, H., Mackensen, A., Pancost, R.D., 2019. Insensitivity of alkenone carbon isotopes to atmospheric $\mathrm{CO} 2$ at low to moderate CO2 levels. Climate of the Past 15, 539-554.

Beaufort, L., Barbarin, N., Gally, Y., 2014. Optical measurements to determine the thickness of calcite crystals and the mass of thin carbonate particles such as coccoliths. Nature Protocols 9, 633-642.

Beaufort, L., Gally, Y., Suchéras-Marx, B., Ferrand, P., Duboisset, J., 2021. Technical Note: A universal method for measuring the thickness of microscopic calcite crystals, based on Bidirectional Circular Polarization. Biogeosciences 18, 775-785. 
Beaufort, L., Heussner, S., 1999. Coccolithophorids on the continental slope of the Bay of Biscay production, transport and contribution to mass fluxes. Deep-Sea Research Part II: Topical Studies in Oceanography 46, 2147-2174

Beaufort, L., Probert, I., De Garidel-Thoron, T., Bendif, E.M., Ruiz-Pino, D., Metzl, N., Goyet, C., Buchet, N., Coupel, P., Grelaud, M., Rost, B., Rickaby, R.E.M., De Vargas, C., 2011. Sensitivity of coccolithophores to carbonate chemistry and ocean acidification. Nature 476, 80-83.

Beuvier, T., Probert, I., Beaufort, L., Suchéras-Marx, B., Chushkin, Y., Zontone, F., Gibaud, A., 2019. $\mathrm{X}$-ray nanotomography of coccolithophores reveals that coccolith mass and segment number correlate with grid size. Nature Communications 10, 751.

Bollmann, J., 1997. Morphology and biogeography of Gephyrocapsa coccoliths in Holocene sediments. Marine Micropaleontology 29, 319-350.

Bollmann, J., 2014. Technical Note: Weight approximation of coccoliths using a circular polarizer and interference colour derived retardation estimates - (The CPR Method). Biogeosciences 11, 18991910.

Bollmann, J., Herrle, J.O., Cortés, M.Y., Fielding, S.R., 2009. The effect of sea water salinity on the morphology of Emiliania huxleyi in plankton and sediment samples. Earth and Planetary Science Letters 284, 320-328.

Bolton, C.T., Hernandez-Sanchez, M.T., Fuertes, M.-A., Gonzalez-Lemos, S., Abrevaya, L., MendezVicente, A., Flores, J.-A., Probert, I., Giosan, L., Johnson, J., Stoll, H.M., 2016. Decrease in coccolithophore calcification and $\mathrm{CO}_{2}$ since the middle Miocene. Nature Communications 7 , 10284.

Bornemann, A., Mutterlose, J., 2006. Size analyses of the coccolith species Biscutum constans and Watznaueria barnesiae from the Late Albian "Niveau Breistroffer" (SE France): taxonomic and palaeoecological implications. Géobios 39, 599-615

Bown, P.R., Gibbs, S.J., Sheward, R.M., O'Dea, S.A., Higgins, D., 2014. Searching for cells: the potential of fossil coccospheres in coccolithophore research, in: Young, J.R., Gallagher, L.T. (Eds.), Coccolithophores 2014 workshop volume. Journal of Nannoplankton Research, Heraklion, pp. 5-21.

Daniels, C.J., Sheward, R.M., Poulton, A.J., 2014. Biogeochemical implications of comparative growth rates of Emiliania huxleyi and Coccolithus species. Biogeosciences 11, 6915-6925.

Devroye, L. 1986. Non-uniform random variate generation. Springer-Verlag, New York, USA, 843 pp.

Erba, E., Bottini, C., Weissert, H., Keller, C.E., 2010. Calcareous nannoplankton response to surfacewater acidification around Oceanic Anoxic Event 1a. Science 329, 428-432.

Ferreira, J., Mattioli, E., van de Schootbrugge, B., 2017. Palaeoenvironmental vs. evolutionary control on size variation of coccoliths across the Lower-Middle Jurassic. Palaeogeography, Palaeoclimatology, Palaeoecology 465, Part A, 177-192.

Fuertes, M.-A., Flores, J.-A., Sierro, F.J., 2014. The use of circularly polarized light for biometry, identification and estimation of mass of coccoliths. Marine Micropaleontology 113, 44-55.

Gardin, S., Krystyn, L., Richoz, S., Bartolini, A., Galbrun, B., 2012. Where and when the earliest coccolithophores? Lethaia 45, 507-523.

Gibbs, S.J., Poulton, A.J., Bown, P.R., Daniels, C.J., Hopkins, J., Young, J.R., Jones, H., L., Thiemann, G.J., O'Dea, S.A., Newsam, C., 2013. Species-specific growth response of coccolithophores to Palaeocene-Eocene environmental change. Nature Geoscience 6, 218-222.

Gollain, B., Mattioli, E., Kenjo, S., Bartolini, A., Reboulet, S., 2019. Size patterns of the coccolith Watznaueria barnesiae in the lower Cretaceous: Biotic versus abiotic forcing. Marine Micropaleontology 152, 101740.

González-Lemos, S., Guitián, J., Fuertes, M.Á., Flores, J.A., Stoll, H.M., 2018. Technical note: An empirical method for absolute calibration of coccolith thickness. Biogeosciences 15, 1079-1091. 
Hagino, K., Tomioka, N., Young, J.R., Takano, Y., Onuma, R., Horiguchi, T., 2016. Extracellular calcification of Braarudosphaera bigelowii deduced from electron microscopic observations of cell surface structure and elemental composition of pentaliths. Marine Micropaleontology 125, $85-94$

Hammer, Ø., Harper, D.A.T., Ryan, P.D., 2001. PAST: paleontological statistics software package for education and data analysis. Palaeontologia Electronica 4, 1-9.

Henderiks, J., 2008. Coccolithophore size rules - Reconstructing ancient cell geometry and cellular calcite quota from fossil coccoliths. Marine Micropaleontology 67, 143-154.

Henderiks, J., Pagani, M., 2007. Refining ancient carbon dioxide estimates: Significance of coccolithophore cell size for alkenone-based $\mathrm{pCO}_{2}$ records. Paleoceanography 22 .

Henderiks, J., Pagani, M., 2008. Coccolithophore cell size and the Paleogene decline in atmospheric $\mathrm{CO}_{2}$. Earth and Planetary Science Letters 269, 575-583.

Keller, M.D., Selvin, R.C., Claus W., Guillard, R.R.L., 1987. Media for the culture of oceanic ultraphytoplankton. Journal of Phycology 23, 633-638.

Langer, G., Taylor, A.R., Walker, C.E., Meyer, E.M., Ben Joseph, O., Gal, A., Harper, G.M., Probert, I., Brownlee, C., Wheeler, G.L., 2021. The role of silicon in the development of complex crystal shapes in coccolithophores. New Phytologist.

Monteiro, F.M., Bach, L.T., Brownlee, C., Bown, P., Rickaby, R.E.M., Poulton, A.J., Tyrrell, T., Beaufort, L., Dutkiewicz, S., Gibbs, S.J., Gutowska, M.A., Lee, R., Riebesell, U., Young, J.R., Ridgwell, A., 2016. Why marine phytoplankton calcify. Science Advances 2, e1501822.

Müller, M.N., Antia, A.N., LaRoche, J., 2008. Influence of cell cycle phase on calcification in the coccolithophore Emiliania huxleyi. Limnology and Oceanography 53, 506-512.

Plancq, J., Grossi, V., Henderiks, J., Simon, L., Mattioli, E., 2012. Alkenone producers during late Oligocene-early Miocene revisited. Paleoceanography 27, PA1202.

Roth, P.H., 1989. Ocean circulation and calcareous nannoplankton evolution during the Jurassic and Cretaceous. Palaeogeography, Palaeoclimatology, Palaeoecology 74, 111-126.

Sheward, R.M., Poulton, A.J., Gibbs, S.J., Daniels, C.J., Bown, P.R., 2017. Physiology regulates the relationship between coccosphere geometry and growth phase in coccolithophores. Biogeosciences 14, 1493-1509.

Shingleton, A.W., 2010. Allometry: The study of biological scaling. Nature Education Knowledge 3, 2.

Suchéras-Marx, B., Henderiks, J., 2014. Downsizing the pelagic carbonate factory: Impacts of calcareous nannoplankton evolution on carbonate burial over the past 17 million years. Global and Planetary Change 123, 97-109.

Suchéras-Marx, B., Mattioli, E., Pittet, B., Escarguel, G., Suan, G., 2010. Astronomically-paced coccolith size variations during the early Pliensbachian (Early Jurassic). Palaeogeography, Palaeoclimatology, Palaeoecology 295, 281-292.

Taylor, A.R., Russell, M.A., Harper, G.M., Collins, T.F.T., Brownlee, C., 2007. Dynamics of formation and secretion of heterococcoliths by Coccolithus pelagicus ssp. braarudii. European Journal of Phycology 42, 125-136.

Walker, C.E., Taylor, A.R., Langer, G., Durak, G.M., Heath, S., Probert, I., Tyrrell, T., Brownlee, C., Wheeler, G.L., 2018. The requirement for calcification differs between ecologically important coccolithophore species. New Phytologist 220, 147-162.

Young, J.R., Ziveri, P., 2000. Calculation of coccolith volume and its use in calibration of carbonate flux estimates. Deep-Sea Research Part II: Topical Studies in Oceanography 47, 1679-1700.

Young, J.R., Geisen, M., Cros, L., Kleijne, A., Sprengel, C., Probert, I., Ostergaard, J., 2003. A guide to extant coccolithophore taxonomy. Journal of Nannoplankton Research Special Issue 1, 1-125 
Zeebe, R.E., Westbroek, P., 2003. A simple model for the $\mathrm{CaCO}_{3}$ saturation state of the ocean: The "Strangelove," the "Neritan," and the "Cretan" Ocean. Geochemistry, Geophysics, Geosystems 4, 1104.

Zhang, Y.G., Henderiks, J., Liu, X., 2020. Refining the alkenone- $\mathrm{pCO}_{2}$ method II: Towards resolving the physiological parameter 'b'. Geochimica et Cosmochimica Acta 281, 118-134. 


\section{APPENDIX}

\section{Analytic solution for Model I, variant \#1, no variability in minimum and maximum diameters}

$C c_{L}$ min and $C c_{L}$ max are, respectively, the minimum and the maximum diameters of the coccoliths. Let $t$ be the relative time during a growth cycle such as $t=0$ corresponds to the beginning of the growth and $t=1$, the end, hence $t \in[0 ; 1]$.

As it is assumed that the cell growth has a linear trend, it yields

$$
C_{C L}(t)=C_{C L} \min +t .\left(C_{C L} \max -C_{C L} \min \right)
$$

with $C_{C L}(t)$ the coccolith diameter produced at time $t$ of the growth phase.

The time $t$ is simulated via a Monte-Carlo sampling in a Uniform law varying between 0 and 1 . It means that the continuous random variable of the time $T \hookrightarrow U(0,1)$

Let $C I$ be the continuous random variable of the simulated coccolith diameter with Model I, variant \#1. $C I$ is a linear transformation of T. Therefore, $C I$ is a uniform distribution (Devroye, 1986, p.569) between $C_{C L} \min$ and $C_{C L} \max$.

Demonstration:

Let $X$ and $Y$ be two continuous random variables. Let assume the linear function $y(x)=a \cdot x+$ $\underline{b}$ with $a, b \in \mathbb{R}$ and $a \neq 0$. The inverse function $x(y)=(y-b) / a$, with derivative $x^{\prime}(y)=1 / a$ Then, $\mathrm{Y}=\mathrm{y}(\mathrm{X})$.

If $X \hookrightarrow U(0,1)$, then $0 \leq X<1$ and $P(0 \leq X<1)=\int_{0}^{1} f(x) d x$, where $f$ is the probability density function ( $p d f$ ) of $X$ and $f(x)=1, \forall x \in[0,1]$.

The function $y$ is strictly increasing, then $0 \leq X<1 \Rightarrow y(0) \leq Y<y(1) \Rightarrow a \leq Y<a+b$ Then,

$$
\begin{gathered}
P(0 \leq X<1)=P(a \leq Y<a+b)=\int_{0}^{1} f(x) d x \\
P(a \leq Y<a+b)=\int_{y(0)}^{y(1)} f(x(y)) \frac{d x}{d y} d y \\
P(a \leq Y<a+b)=\int_{a}^{a+b} f(x(y)) x^{\prime}(y) d y
\end{gathered}
$$

Let $\mathrm{g}$ be the function equal to: $g(x)=f(x(y)) \cdot x^{\prime}(y)=1 \times 1 / a=1 / a$

In our case, $a=C_{C L} \max -C_{C L} \min$, then $g(x)=1 /\left(C_{C L} \max -C_{C L} \min \right)$, which is the pdf of a uniform distribution between $C c_{L}$ min and $C c_{L}$ max.

Therefore, $C I \hookrightarrow U\left(C_{C L} \min , C_{C L} \max \right)$

\section{Analytic solution for Model II, variant \#1, no variability in minimum and maximum diameters}

The time $t$ is simulated via a Monte-Carlo sampling in a Uniform law varying between 0 and 1 . It means that the continuous random variable of the time $T \hookrightarrow U(0,1)$.

Similarly to the Model I, the cell growth is considered as linear:

$$
C_{C L}(t)=C_{C L} \min +t .\left(C_{C L} \max -C_{C L} \min \right)
$$

with $C_{C L}(t)$ the coccolith diameter produced at time $t$ of the growth phase.

Let $C I I$ be the continuous random variable of the simulated coccolith diameter with Model II, variant $\# 1$.

The coccolith diameter $c$ is simulated via a Monte-Carlo sampling in a Uniform law varying between $C_{C L}$ min and $C_{C L}(t)$. It means that the continuous random variable $C I I(t) \hookrightarrow U\left(C_{C L} \min , C_{C L}(t)\right)$. The model is graphically represented in the Figure 6. 


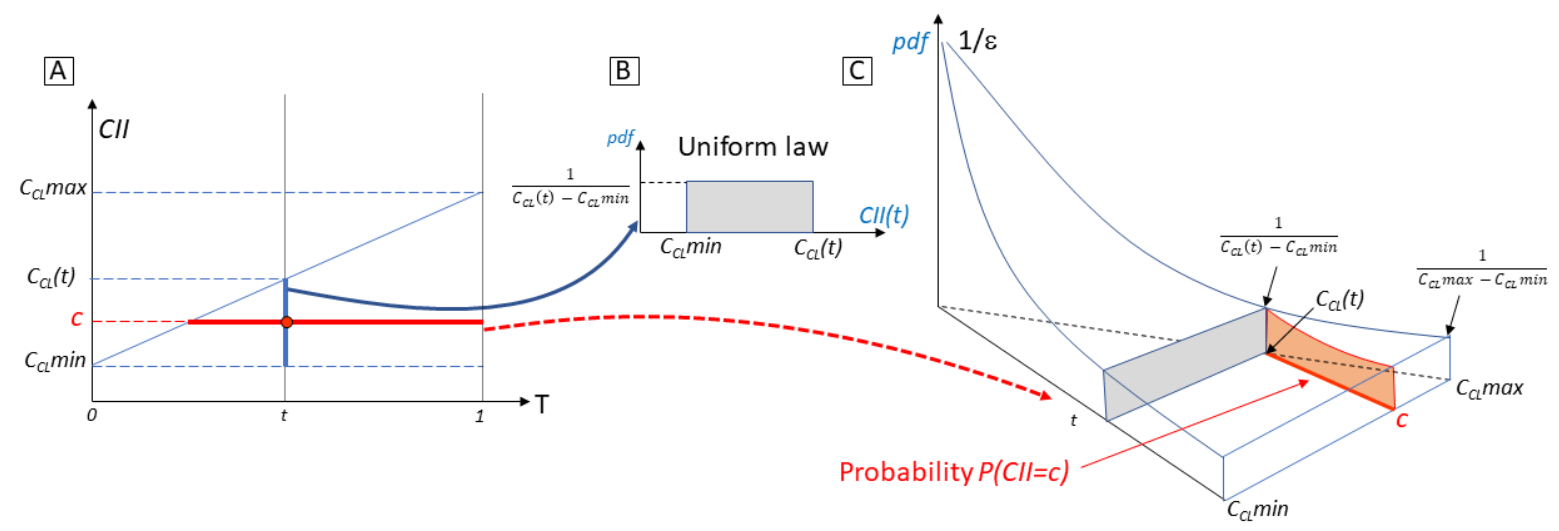

Figure 6: Diagram showing the graphical representation of the $p d f$ variability in function of $t$. A. Diagram of the implemented model II. B. The local uniform pdf law of CII(t) corresponding to the random variable at time $t$. C. diagram showing the variability of the $p d f$ in function of $t$. On the diagram, $1 / \varepsilon$ is set because $\lim _{c \rightarrow C_{C L} \min } \frac{1}{c-C_{C L} \min }=+\infty$.

By considering the Figure 6C, it may be observed that the total probability of choosing $c$ along time is the integral of the local $p d f$ from $x=c$ to $x=C_{C L} \max$.

Let consider $A \in \mathbb{R}$ the normalization factor of the $p d f$, it may be written that:

$$
\begin{gathered}
P(C=c)=A \cdot \int_{C}^{C_{C L} \max } \frac{d x}{x-C_{C L} \min }=\left[A \cdot \ln \left(x-C_{C L} \min \right)\right]_{C}^{C_{C L} \max } \\
P(C=c)=\left[A \cdot \ln \left(x-C_{C L} \min \right)\right]_{C}^{C_{C L} \max }=A\left[\ln \left(C_{C L} \max -C_{C L} \min \right)-\ln \left(c-C_{C L} \min \right)\right] \\
P(C=c)=-A\left[\ln \left(\frac{c-C_{C L} \min }{C_{C L} \max -C_{C L} \min }\right)\right]
\end{gathered}
$$

To compute $A$, the equation below must be honoured:

$$
\int_{C_{C L} \min }^{C \max }-A \ln \left(\frac{c-C_{C L} \min }{C_{C L} \max -C_{C L} \min }\right) d c=1
$$

The function, on which to apply an integral calculus, is of the following shape:

$$
\ln (a x+b) \text { with } a=1 /\left(C_{C L} \max -C_{C L} \min \right), b=-C \min /\left(C_{C L} \max -C_{C L} \min \right) \text { and } \frac{b}{a}=-C_{C L} \min
$$

By considering: $u(x)=\ln (a x+b)$ and $v^{\prime}(x)=1$, then: $u^{\prime}(x)=\frac{a}{a x+b}$ and $v(x)=x+b / a$ and by using the formula of the integration by parts, it yields:

$$
\begin{aligned}
&-A \cdot \int_{C_{C L} \min }^{C_{C L} \max } \ln (a x+b) d x=-A \cdot\left\{\left[\left(x+\frac{b}{a}\right) \ln (a x+b)\right]_{C_{C L} \min }^{C_{C L} \max }-\int_{C_{C L} \min }^{C_{C L} \max } \frac{a x+b}{a x+b} d x\right\}=1 \\
&-A \cdot\left\{\left[\left(x+\frac{b}{a}\right) \ln (a x+b)\right]_{C_{C L} \min }^{C_{C L} \max }-\int_{C_{C L} \min }^{C_{C L} \max } d x\right\}=1 \\
&-A \cdot\left\{\left[\left(x+\frac{b}{a}\right) \ln (a x+b)\right]_{C_{C L} \min }^{C_{C L} \max }-[x]_{C_{C L} \min }^{C_{C L} \max }\right\}=1
\end{aligned}
$$

The first part of the integration vanishes because:

$$
\text { - } \lim _{x \rightarrow C_{C L} \min }\left(x-C_{C L} \min \right) \ln \left(\frac{x-C_{C L} \min }{C_{C L} \max -C_{C L} \min }\right)=0
$$


- $\left(C_{C L} \max -C_{C L} \min \right) \ln \left(\frac{C_{C L} \max -C_{C L} \min }{C_{C L} \max -C_{C L} \min }\right)=\left(C_{C L} \max -C_{C L} \min \right) \cdot \ln (1)=0$

Thus, it yields:

$-A\left(C_{C L} \max -C_{C L} \min \right)=1$ thus: $A=1 /\left(C_{C L} \min -C_{C L} \max \right)$

Therefore, the probability density function of the model II may be written as:

$$
f(x)=\frac{1}{C_{C L} \min -C_{C L} \max } \ln \left(\frac{c-C_{C L} \min }{C_{C L} \max -C_{C L} \min }\right)
$$

An example of the density function shape is shown in Figure 7, computed with $C_{C L} \min =15$ and $C_{C L} \max =25$.

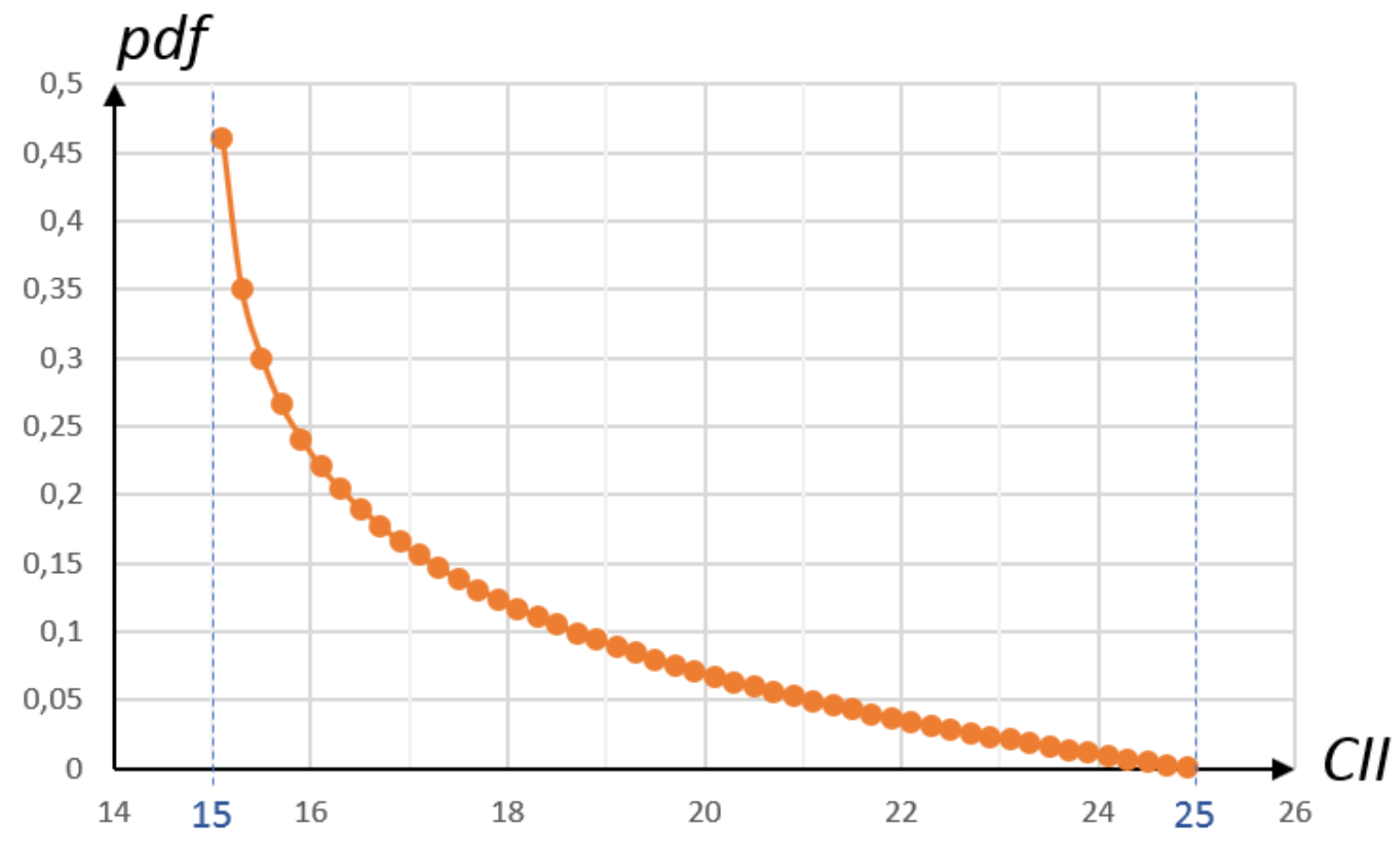

Figure 7: Example of a computed $p d f$ of CII, using $C_{C L} \min =15$ and $C_{C L} \max =25$. The sample is evenly defined every 0.1 between 15 and 25 . 